Article

\title{
Deindustrialisation, Community, and Adult Education: The North East England Experience
}

\author{
Jo Forster *, Margaret Petrie and Jim Crowther \\ Moray House School of Education, University of Edinburgh, Edinburgh EH8 8AQ, UK; \\ Jim.Crowther@ed.ac.uk (J.C.); Margaret.Petrie@ed.ac.uk (M.P.) \\ * Correspondence: Jo.Forster@ed.ac.uk; Tel.: +44-753-824-2084
}

Received: 12 September 2018; Accepted: 18 October 2018; Published: 23 October 2018

check for updates

\begin{abstract}
This article argues for the continued importance of adult education in communities, an approach to adult education which has been maligned and ignored in policy that has, instead, incessantly prioritised employability skills training. The significance of adult education in communities is that it seeks to build the curriculum from the interests, aspirations, and problems that people experience in their everyday lives by providing opportunities for individual and collective change (more below). We draw on data taken from a study by one of the authors, which used a life history approach to explore the outcomes for 14 people from the deindustrialised North East England of participation in either employability skills training or community adult education. We document several themes through these stories: churning, surveillance, precarity, demoralisation, ontological insecurity, and personal renewal.
\end{abstract}

Keywords: deindustrialisation; government programmes; community adult education; social class; gender

\section{Introduction}

The context for our argument is the historical experience of deindustrialisation in North East England. The geographical communities in North East England where this research was conducted are the former coalfield area of East and North West Durham and a former steel town in North West Durham. These were once thriving, working class communities that were dependent on the coal and steel industries for their livelihoods until the 1980s. Boniface et al. (2001, pp. 120-35) argue that "communities were created around these industries and became dependent on them". These industries had always been subject to the turbulence of global markets, but not to closure and wholesale job loss. In 1947, the East Durham coalfield was nationalised and in 1967, the steel industry in North West Durham was also nationalised (Beynon et al. 1991, p. xv). During the post-war period, the Ministry of Fuel and Power's employment policies called for coal and steel output to be maximised. The politicians argued successfully that, in order to achieve this, no new male employing manufacturing industries should be introduced into these coal and steel working areas. New industries would, they believed, attract miners and steel workers to take up alternative employment and this would reduce coal and steel output. This policy left communities dependent on these two heavy industries and bereft of alternative work when deindustrialisation of the nationalised industries took place in the 1980s (Beynon et al. 1991, pp. 102-6).

The Miner's Strike of 1984-1985 was to prove the final nail in the coffin of the mining industry in the area. The Miners' Strike was not about wages, but about retaining jobs and keeping collieries open, largely in communities that were dependent on these industries. When the miners returned to work after the disastrous upheaval of the strike, they were, nevertheless, shocked at the announcement of a series of colliery closures that included Horden and Easington collieries in North East England. Despite earlier predictions (Lord Robins cited in Beynon et al. 1986, p. 4351) of vast reserves of coal to 
be mined over the next 100 years, it was announced on their return from the Miners' Strike that only five years of coal reserves remained. The reason given by the National Coal Board for these closures was based on the exhaustion of coal and that the deep mines were no longer cost-effective as coal could be purchased more cheaply on the global market. More collieries proceeded to close across Durham, with a further 50,000 miners' jobs lost to the industry (Beynon et al. 1991, p. 3). The optimistic view of deindustrialisation, presented during this period, was a beneficial way of restructuring the economies of areas which were dependent on heavy industries, such as coal and steel production. As these old industries closed down, the opportunity for lighter, better paid, more high-tech work would take their place. A more critical view was that deindustrialisation was part of a class-based struggle-particularly in the north-east of England-which was waged particularly against the mine workers and their union, aiming to weaken working class identities and organisation.

Deindustrialisation in the 1980s was accelerated by a neoliberal political ideology which gathered pace in the UK from the first Thatcher government onwards, profoundly reshaping the nature of working class and gendered identities, as we go on to discuss.

\section{Class and Gender in the Context of Economic Decline}

Social class can be framed gradationally or relationally. In the former, social class distinctions are usually related to occupational categories and their class rankings (Savage 2015; Sayer 2015), whereas a relational view of class focuses on the struggles that occur between opposing social classes. The approach taken here relates to a relational perspective on social class. Sayer $(2002$, p. 2) points out that class raises issues of the relative worth of individuals, and about differences between how people are "valued economically, and how they are valued ethically". Morality is not merely a set of norms regarding what is acceptable; it is about something independent of itself-namely, how people as inherently social beings can both harm and be harmed, flourish and suffer, and can live together in ways that have regard for their well-being or not (Sayer 2010, pp. 166-67). Class matters as it is how individuals of different social classes, with different levels of capital, behave towards each other in the "social field" that can create "unequal possibilities for flourishing and suffering" (Sayer 2005, p. 218).

One of the most important features of class inequalities is that they present people with unequal bases for respect, not just by being objects of unwarranted respect or disdain, but as having unequal access to the practices and goods that allow them due respect or conditional recognition (Skeggs 1997). Being able to participate in practices and such relationships and gain their internal goods (development of skills and achievement) if one so wishes is crucial for well-being, though access to them differs radically across the key social divisions of gender, class, and 'race', and across other divisions too (Sayer 2005, p. 955). As Skeggs notes:

To make class invisible is to abdicate responsibility (through privilege) from the effects it produces. To think that class does not matter is only a prerogative of those unaffected by the deprivations and exclusions it produces. (Skeggs 1997, p. 7)

Structured patterns of work and kinship provide a sense of security to local people. According to Walkerdine (2009, p. 63), such practices provide "ontological security", which she describes as "the rhythm and patterns of everyday life, both materially and emotionally, that provided the community with a sense of safety". Deindustrialisation of the traditional industries ruptured the "containing skin" (Walkerdine 2010, p. 91) that had held these communities together like glue. This skin had affectively contained anxieties and feelings of insecurity through the routine of work, kinship practices, and affective work and social relationships. Once ruptured, it shifted the mental state of the population from one of "ontological security" to "ontological insecurity". This shift was to change the way of life for both men and women and their future generations when work disappeared for the men.

The traditional industrial order had depended upon a stable, gendered division of labour, but the restructuring of the economy to low-paid, non-unionised, precarious, feminised jobs shifted the balance 
of power within home life in the latter part of 20th century. Women took up jobs out of financial necessity, leaving men at home. Family life fragmented as redundant men became (self)-excluded from a workplace that did not offer masculine jobs. What followed was often poor mental health, and alcohol and drug abuse. This shattering of working class family life remains prevalent in the future generations of redundant industrial coal and steel workers, as we go on to discuss.

Men and women responded differently to deindustrialisation because it entailed women moving from respectable domesticity into a precarious, low-paid labour market. Mackenzie and Rose (1982, p. 181) point out that women provided a "cheap and flexible labour force that worked for pin money". 'Pin money' was an expression used when men and women worked in traditional roles and men were the primary breadwinners within the household. This was a trivial amount of money given to women by men for personal use. Deindustrialisation and the changes that were taking place in family life changed the meaning of 'pin money' significantly. This was now money earned by women in a low-paid labour market to ensure that there was some financial safety net around the family when men had no work. Harkness et al. $(1994$, p. 1) point out that, "women's earnings make an important contribution towards keeping families out of poverty. For couples, poverty rates would have been up to 50\% higher in 1990/91 without women's pay". According to Mackenzie and Rose (1982, p. 181):

This growth in female employment grew dramatically in the region of North East England ... industrial restructuring is not gender-neutral [as] replacement ... [of] heavy industries by light manufacturing and service work ... was a search for cheap, more docile labour. This changing division of labour as a whole implies both a changing spatial and sexual division.

Men now found their role restructured as they were no longer the breadwinner, but at home in a domestic role and facing long-term unemployment. Pimlott (1981, p. 51) explained that unemployed men saw redundancy as a sign of personal failure although its true cause was a crisis within capitalism that was beyond their control. Women who had stepped over the threshold of the domestic sphere into the world of work faced the challenge of managing the dual roles of work and home. Changes in behaviour became visible in family life when the separate spheres of home and work fractured and women went to work and men stayed at home. This socio-economic change within family life became visible as conflict in women's lives. According to Seabrook (1982, pp. 1-12), "limitless leisure" was not healthy for family life as "violence, marital breakdown and mental health difficulties often followed". Violence against women in County Durham continues to increase. County Durham Domestic Abuse and Sexual Violence Strategy 2015-2018 (County Durham Domestic Abuse and Sexual Violence Strategy 2015-2018, p. 17-18) points out that the Office of National Statistics in 2014 estimated that the $15+$ age group of County Durham was 434,900 of which $48.7 \%$ were male $(211,741)$ and $51.3 \%$ were female $(223,206)$. The "ready reckoner" produced by the Home Office to estimate numbers and costs of violence against women and girls' estimates that in County Durham, based on the population size and the regional prevalence rate from the British Crime Survey, 17,285 women and girls aged 16-59 have been victims of domestic abuse in the last year; 7,223 have been victims of sexual assault and 20,553 have been victims of stalking.

Kinship or communal self-help that was based on mutual support and aid formed a safety net around industrial communities. Kinship was also a form of social production as caregivers were pre-dominantly women who cared for children, the elderly, and sick within the extended family and neighbourhood. Such collective ways of organising enabled communities to survive hardship, and kinship also provided a lifeline of emotional support and reduced anxiety within the population. According to Walkerdine and Jimenez (2012, p. 48), kinship is more than providing food and clothing through in-kind transactions as it provides "psychosocial mutual support that is affective and social". Income that was once supplemented through kinship practices of mutual aid was replaced by meagre state welfare benefits. Aid for food and clothing was provided at the loss of one's privacy through local and central government agencies. 
The economic and social processes of deindustrialisation still resonate in the present and continue to shape behaviour. A loss of routine, previously provided through work, has resulted in increased anxiety and brought about poor mental health, in both men and women. The following statistics focus attention on how poor mental health has now extended into future generations of men and women who live in these communities. The County Durham Joint Strategic Needs Assessment, Key Messages (2015) (County Durham Joint Strategic Needs Assessment. Key Messages 2015, pp. 5-6) points out that there are over 4600 people in County Durham registered with GPs with a diagnosis of mental illness. More than 50,000 have a common mental disorder, for example, anxiety and depression. The number of referrals for Adult Mental Health Professional (AMHP) assessments for adults with mental health needs increased by $40 \%$ when comparing $2010 / 11$ figures with $2014 / 15$, and by $26.9 \%$ when comparing 2014/15 figures with 2015/16. Between 2012 and 2014, the suicide rate (13.3 per 100,000 population) was higher than the England average of 8.9. The County Durham Public Mental Health Strategy (County Durham Public Mental Health Strategy 2013-2017) points out that in County Durham, 81\% of those who took their own life between 2005 and 2012 were male rather than female and had a peak age of 40-49. A total of $62 \%$ were divorced and $32 \%$ lived alone. A significant number of those who committed suicide were found to have diagnosed mental health problems (58.9\%). Furthermore, $30 \%$ were recorded as alcohol-dependent, $13 \%$ were recorded as users of illicit drugs, and $39.2 \%$ had a history of self-harm. Self-harm is an expression of personal distress and can be a risk factor forsubsequent suicide. Self-harm is more common among those who are socio-economically disadvantaged and have a severe lack of social support. County Durham has a significantly higher self-harm directly standardised rate than England, with 343 hospital admissions during 2010/11 compared to the England average of 207. The County Durham Alcohol Harm Reduction Strategy (2015) points out that County Durham has the third highest rate of mortality from chronic liver disease among females in the North East. Alcohol-related deaths for women in the county increased in 2013 to a rate of 35.7 per 100,000 and this value is now significantly higher than the rate for England at 28.4 per 100,000. (p. 12).

Wray and Stephenson (2012, pp. 329-36) point out that the consequences for mining communities in County Durham resulted in "depression and loss of self-worth and confidence at an individual and collective level". How was adult education able to respond to these developments?

\section{From Adult Education to Lifelong Training}

Policies developed at a European and UK level have re-configured adult education in favour of learning for the economy. The purpose of adult education for economic reasons has been supported through European Union policy and a plethora of white papers and quangos from the 1980s onwards in England. This trend transformed the landscape of adult education provision from traditional models of community education whereby learners could collectively generate knowledge on matters of concern to them in their everyday lives to bring about social change, to one of government programmes. Government training programmes for 'employability' were seen as a solution to the social and economic inclusion of the unemployed.

The scale of the shift in resourcing to a more instrumental version of provision in England and Wales is evident in the following figures. The Skills Funding Agency 2013 (the Executive Agency of the Department for Business Innovation and Skills) in 2013 to 2014 was allocated $£ 3.6$ billion to support three million adult learners, of which only $£ 210$ million per annum remained protected for Community Learning until 2016. After 2016, Community Learning would no longer have a ring-fenced budget (Foster 2017, p. 16). The goal had increasingly become focused on more training for economic success. Austerity measures taken by the Conservative-Liberal Coalition Government (2010) announced public sector cuts of an estimated $£ 210$ billion (10.3\% GDP) (Trade Union Council 2014, p. 13). As austerity unfolded, a picture emerged of drastically scaled-back services of local voluntary organisations (VONNE 2014, p. 4). This significantly cut back spaces for community adult education provision within voluntary organisations. According to O'Hara (2014, p. 249) “In the North East, the region most hit by cuts and austerity, the impact on voluntary agencies was shattering". 
Instrumental to justifying the above pattern of resourcing has been a discourse of "learning to be productive" (Biesta 2006) that has been reiterated by, national, European, and international organisations. For example, the Organisation for Economic Co-operation and Development (OECD) Report, Lifelong Learning for All (1997), created a significant shift by referring to lifelong learning as the "development of human capital", so that one participates in learning in order to constantly update one's skills due to the changing nature of the global economy. Coffield (1999, p. 480) points out that in linking people's individual skills development to their own and their nation's economic competitiveness and prosperity, education had become a "mere instrument of the economy".

Likewise, the European Union expected lifelong learning through vocational training to contribute towards solving the problems of economic competitiveness and an unemployment crisis that was leading to social exclusion and marginalisation within populations, and it saw this as a threat to political and social stability (Commission of the European Communities CEC, p. 117-8). The focus of the OECD labour market policy was to target "low-paid and unskilled job seekers" (OECD 1998, p. 4 cited in McQuaid and Lindsay 2005, pp. 197-9). However, the Luxembourg Strategy (1997) set out a new policy direction of "employability" to address this crisis (Brine 2006, pp. 649-52). 'Employability' was a significant shift from vocational learning. 'Employability' was now the responsibility of an individual to become employed, rather than the state of employment itself. This is a state of constantly becoming ready for the labour market through repetitive training to obtain the characteristics to constantly create a new economic identity despite deficient labour market conditions. This model has seen the rise of a new role of the employability tutor. Coffield $(2006$, p. 8) explains that 'employability' is turned into a "private trouble of constant training".

The concept of employability has become closely tied to the stricter Welfare Reform Act (2009, 2012a, 2012b, 2013, 2016) that emphasised mandatory work activity schemes for welfare claimants. Since 2012, employability welfare to work policies have focused on mandatory, "client-centred" training programmes. The neoliberal state seeks to promote the freedom of individuals to determine their own fate (Barratt cited in Danson et al. 2015, p. 286). Unfortunately, for the unemployed in government programmes, this freedom is restricted and disciplinary. These programmes have an increasingly stringent job-seeking regime in an attempt to force unemployed people to enter low-paid, precarious work (if available). This process of 'churning' learners through 'welfare to work' programmes is a form of social control and discipline, with the underlying political aim of changing attitudes towards low-paid, short-term work that "does not provide stepping stones to something better, nor does it move people out of poverty" (Shildrick 2015, p. 6). Social control models are programmes that are concerned solely with encouraging the unemployed to enter employment (Johnston 1992, p. 67).

Through attendance in government programmes, learners are subjected to coercive methods through psychological interventions that will bring about attitudinal behavioural changes, as they must develop work-appropriate attitudes to achieve employability. Compulsory coercive methods of "positive affect" are implemented through "psychological interventions that aim to modify cognitive function or emotional disposition" (Friedli and Stearn 2015, p. 42). It is believed that such interventions will change behaviours and so enable learners to obtain work, which is a paradox given the market failure in deindustrialised areas. Surveillance and sanctioning (loss of benefits) of learners are also part of this panopticon milieu that demands that learners are complicit with the system. This increases anxiety within learners who have lived with ontological insecurity throughout their lives and who now find themselves socially controlled through repetitive government programmes as "outcasts on the inside" (Bourdieu and Champagne cited in Reay 2006, p. 298).

\section{Adult Education in Communities}

In contrast to the dominant economic model of learning, there are alternative traditions of adult education. The following four traditions of adult education emphasise very different rationales and practices: these are the liberal, personal development, radical, and social purpose traditions (Bowl 2014, pp. 10 \& 34). 
Liberal education is "the pursuit of knowledge for purposes of enhanced aesthetic appreciation, increased intellectual awareness or heightened analytical powers" (Brookfield 1983, p. 173). Liberal education, with its critical and enquiring approach, offered an enriching experience in science, the arts, and literature, and had "an emphasis on knowledge for its own sake rather than for vocational or utilitarian purposes" (Taylor 1986, p. 9). In the 19th century, a liberal education was for the elite rather than the working class, for whom public education was to meet the demands of industry (Westergaard and Resler cited in Taylor 1986, p. 9). In the 1970s and 1980s, the liberal model of adult education was extended to the working class through a range of certificated and non-certificated courses delivered across a plethora of community sites (Fletcher, cited in Brookfield 1983, p. 66). This model is identified with the harmonious community of 'gemeinschaft', where everyone is seen to be in harmony with one another.

The liberal model fails to identify the socio-economic inequalities that exist in working class communities and consequently fails to provide a curriculum relevant to the social reality of working class lives (Brookfield 1983, p. 67). Programmes offered were delivered through pre-written learning materials that were thought to meet learners' needs, rather than starting with the inequalities experienced by the learner (Lovett 1975, pp. 12-13). The adult educator used traditional pedagogical methods to transmit knowledge to learners rather than encouraging dialogue and giving recognition to the life experiences and social realty of learners in the educational process. According to Jackson (1995, p. 184):

Adult education constructs knowledge and does not merely pass it on ... It was precisely by engaging directly with the interests of people in working-class communities facing major problems, that adult education seemed to have a real if marginal contribution to make in meeting the challenge which they faced.

For Freire (1972, pp. 45-47), such traditional pedagogical methods of "banking" are unlikely to develop a critical consciousness that enables people to identify and challenge the inequalities in their lives. It was therefore considered that the liberal model did not challenge structural inequalities or encourage a voice and loyalty to a community, but only provided knowledge for its own sake. Today, liberal education that was once concerned with "culture and humanities" (Jarvis 2010, p. 53) has now been reduced to "a form of therapy concerned with health and self-improvement" (Thompson 2007, p. 166). It has primarily become a "middle class leisure pursuit" purchased by the consumer (Bauman, cited in Jarvis 2010, p. 54). In contrast to the liberal model of education, there are alternative traditions of adult education, such as personal development and social purpose models that offer those experiencing socio-economic inequalities an education related to the social reality of their lives, and enable them, at times, to challenge and change oppressive structures. These models suffered a demise when adult education was reconfigured in favour of learning for the economy at the expense of the personal and democratic strands of education. Yet it is precisely these models that offer an alternative experience to the limitations of employability programmes and the liberal model.

The personal development model of community adult education provides a starting point from which to begin to learn. People have different starting points which motivate them to learn, and that sets them off in different trajectories. Personal development can be individualistic and therapeutic or it can be a positive experience that enables people to connect with others and to progress to another stage with new found confidence. How people start and where they end up may be very different. Bowl (2014, p. 10) refers to it as a humanistic approach concerned with personal growth and development, and self-actualisation. Bowl, drawing on the influential work of Carl Rogers, ties in personal and social development with therapeutic education (Rogers cited in Bowl 2014, p. 10).

Today, therapeutic education is associated with a curriculum based on happiness and wellbeing to build emotional resilience and make individuals feel better, more positive, and confident about themselves. It encourages learners to get in touch with their feelings and respond to their experiences emotionally rather than intellectually. This model diminishes the idea of individuals as agents who 
can fulfil their potential by transforming their lives and contribute to bringing about social change to individuals who are 'dysfunctional' or victims due to their experiences. This model may fill a gap between liberal education for its own sake and the economic model for skills training. However, it can be corrosive as individuals become introspective in focusing on their happiness and wellbeing rather than realising their potential (Ecclestone and Hayes 2009, p. 86).

Personal development can also offer a liberating learning experience to those seeking a fresh purpose in life. Personal development can be a precursor to the empowerment of an individual or group. This is an educational process whereby individuals and groups begin to become aware of their social world, class, race, and gender, in addition to the oppressive structures and dominant culture within which they live. They become aware of their ability to act and have a voice on behalf of themselves and others to challenge inequality. Personal development may reduce isolation, provide mutual support, and give a thirst for more radical education and access to broader social networks that will enable the individual to make a valuable contribution to the community. Willis (1991, p. 74) points out that the personal development tradition of adult education, "increased self-esteem, empowerment, optimism and hope. It embraces a sense of confidence ... and a desire to collaborate for human betterment".

Social purpose education is aimed at the working class who experience socio-economic inequalities and are seeking social and political change (Taylor 1986, p. 8). Social purpose education is where "really useful knowledge" is developed to help people understand their social reality and the social inequalities they are experiencing (Johnson 1988, p. 212). It can be characterised in the following terms: (1) participants/learners are treated as citizens and social actors (2) the curriculum reflects shared social and political interests, (3) knowledge is actively and purposefully constructed to advance these collective interests, (4) pedagogy is based on dialogue rather than transmission, (5) critical understanding is linked to social action and political engagement, and (6) education is always a key resource in the broader struggle for social change (Martin 2008, pp. 9-10).

The pedagogical methods of social purpose education are those of Freire's dialogical process. Freire offers an alternative pedagogy to the "banking" method of the transmission of knowledge. Learners are treated as equals to the adult educator and a space is created for negotiation and dialogue between tutor and learner (Freire 1972, p. 53). Freire's dialogical method of critical education engages learners in the social conditions that are oppressing them, and provides a space to question oppressive structures. Through dialogue, learners begin to critically reflect on their situation and develop a political consciousness that challenges them to take action. This process is known as "conscientization", which is the deepening of awareness followed by action that contributes to social change. Barr (1999, pp. 14-15) points out that, "Freire's educational method rests, crucially, on developing with people a notion of themselves as subjects, able to determine their situation rather than being mere objects of it".

Providing adult education spaces where "private troubles" become collective "public issues" (Mills [1959] (1970) and voices are heard to challenge structural socio-economic inequalities or to rationalise problems rather than blame others strengthens subjectivity and is also a force for community cohesion. This claim is clearly substantiated in the following data.

\section{Methodology}

Deindustrialisation was not willed or initiated by the individuals in this study. In order to make sense of these experiences, the most fruitful way to gain an insight into the effects of deindustrialisation was through adopting a life history approach to data collection through 14 semi-structured interviews based on the following questions:

- What have been the major effects of de-industrialisation on the lives of the learners in the sample from these communities?

- How has adult education shaped the position, disposition, and identity of the learners studied? 
Life history belongs to the family of biographical methods that "rest on subjective and inter-subjectively gained knowledge and understandings of the life experiences of individuals" (Denzin 1989, p. 28). With its emphasis on 'subjectivity', life history is a "person-centred" approach (Ayers cited in Hatch and Wisniewski 2003, p. 124). In emphasising "intersubjectivity", dialogue, and a reciprocal relationship with the subject, life history seeks to provide an understanding of the subjectivity of each learner studied. In taking this approach, the narrator (the learner) is not subordinate to the researcher, but has an equal status in co-constructing knowledge (Merrill and West 2009, p. 60).

This is ideologically committed research, rather than a study that claims a specious neutrality. Life history study is underpinned by a socialist feminist research approach that views gender and class as being constructed through the symbolic power of a capitalist system. This has created a hierarchy of classes that defines society as those who have value or those who have no value for the economy (Merrill and West 2009, p. 65; Skeggs 2013, p. 2). In constructing knowledge, structure and agency are important to the socialist feminist researcher who seeks to explore the impact of wider structures of inequality on individual subjectivities and to listen to the voice of the marginalised. Chamberlayne et al. (2000) pointed out the importance of a humanistic approach to qualitative research through biographical methods, and called for studies on "individual subjectivities that valued what people had to say, especially those marginalised in society".

A life story is different from a biography as it is "situated in time, culture and place" (Chin cited in Hatch and Wisniewski 2003, p. 115) and within its "social, historical and political context to avoid the trap of disempowering those we seek to empower" (Goodson 1992, p. 6).

\section{Sample}

The two life stories illustrated in this paper are taken from a wider study of data collected from a sample of fourteen learners aged thirty years plus. The Government Programme learners had been mandated to attend 'employability programmes' through Welfare to Work procedures, whereas the community adult education learners had engaged voluntarily with learning due to life changing experiences. All learners in the study had participated in learning for a minimum of two years. Most had no, or low level, qualifications, and some had moderate literacy difficulties. The sample aimed at engaging $50 \%$ men and $50 \%$ women to have equal representation from both genders to inform the study. A thirty years plus cohort was chosen because this age group is more likely than a younger age group to have experienced the process of industrial decline. A sample of eight key stakeholders in adult education was also included in the study to explore how adult education has changed in response to deindustrialisation in these communities.

\section{Ethical Approach}

The safeguards of informed consent, confidentiality, and anonymity were put in place to protect research participants. Ethical guidelines were followed in accordance with University of Edinburgh (2012). Cohen et al. (2011, pp. 75-104) code of ethical practice of a model of informed consent in working with marginalised groups was followed. Written permission to proceed with the research interview was provided by each participant prior to the study through the signing of an informed consent form.

Confidentiality and anonymity was achieved through grounded theory methods and thematic data analysis, where all data collected from participants is collated into codes, categories, and themes. Each life story was anonymised.

\subsection{Case Studies}

Two abbreviated accounts of life stories are outlined, and they show how the subjectivity of each learner was weakened by the effects of de-industrialisation and in the first case study, also by the government programme. Brian's story was selected as it represented the experiences of other learners in the employability programme sample. Churning was a common theme in these stories. A precarious and deficit labour market, in addition to the conditionality of Welfare Reform, 
increased anxiety in Brian and was also a common theme in other learners. Theresa's story was selected as it represented the gendered dimension of deindustrialization commonly experienced by other women in the community education sample whose lives were 'redeemed'. We are not claiming that these two cases are representative of all learners in either employability programmes or community education courses. They are, nonetheless, examples which contain important insights into experiences which go beyond their individual accounts.

\subsubsection{Case Study 1}

Brian is in his 30s and lives at home with his mother and sister. He left school with no qualifications and a negative experience of his working class education in the comprehensive educational system. The effects of de-industrialisation left Brian's life lacking the economic security enjoyed by his father and grandfather, who had worked in the traditional industries. He recalls how difficult it was to find work after leaving school: 'After a length of time I am starting to struggle to find work'. Rather than become unemployed, he enrolled as a full time student at a further education college for two years.

On leaving college at eighteen, his search for work proved fruitless. Brian's only option was to move on to welfare benefits, which lasted for four years. Throughout this time, Brian recalls that he attended evening classes for computing to keep himself going; however, he states,

I am starting to struggle ... to keep myself motivated, I did lots of temporary courses on computers at the college at evening classes.

Brian attended in the evening so it would not affect his welfare benefits, as he was required to be available for work that never transpired during the day.

At the age of 22 years, he entered the labour market for the first time 'through an agency on a temporary basis'. He became intermittently employed on short-term agency contracts. This precarious work lasted until 2005 when, for the first time, he finally secured 'permanent' work. However, in the 2008 economic crisis, his job was affected and eventually disappeared in 2010. Since 2010, he has had no choice but to claim welfare benefits. Since 2011, he has been mandated to attend government programmes for employability skills, otherwise his benefits will be sanctioned and eventually stopped.

Brian explains his frustration at the repetitive nature of the Employability Skills Programme: 'for 2 years [I] do the basics on how to look for jobs, how to do CVs, how to act at work, how to treat people at work, how to respect other people'. He is mandated to use these employability skills to seek work by applying for non-existent jobs through the Yellow Pages telephone directory or by cold calling employers to ask if they have work. Despite this negative experience of the process, he acknowledges that the Employability Tutors he has met on the programme are supportive in increasing confidence and self-esteem: 'the tutors back you up and they put you on the right path with confidence'.

He explains, however, his long-term struggle to find work while in attendance at these programmes and the rejection he faces from employers in this deficient labour market area:

The Yellow Pages ... apply . . apply ... apply ... I have been struggling since .. 2010 . . have been trying to get a full or part time vacancy ... just been struggling... I phoned one of the call centres before... how can you have experience if you can't get a job ... you have to get a job to get experience ... give me a try out and see what I am like ... it is just a setback.

He begins to express anger at his situation as he has no control over his life:

I am a bit annoyed about it as I am struggling as it is to get off benefits to get full time work ... it is just hard work... Yeah [been] training for ... 2 years ... and you get setbacks.

Despite having feelings of dismay, self-blame, and a loss of hope, he must continue to comply with the psychological conditionality of being job ready. He indicates, 'I am ... going round in circles getting nowhere'. In his present precarious existence, he cycles around his local area in search of work, but with no success. 


\subsubsection{Case Study 2}

Theresa is 59 and divorced with two grown up children. Her son who lives with her has mental health difficulties. As a young child, Theresa witnessed the closure of the colliery in her village. She explains that this disintegrated the life of this mining village:

When the mine went the community went and a loss of social structure of the community ... people were demoralised.

Theresa found the lack of economic opportunities for men meant she became the main 'breadwinner'. She recalls, 'my husband just picked up jobs when he could'. Theresa, like many women in de-industrialised areas, came to shoulder multiple roles of responsibility as a wife, worker, and mother of two children. A major life changing event brought significant change into her life. She recalls:

I had a breakdown ... I had really lost all confidence ... I had no self-esteem ... I was on anti-depressants.

Theresa freed herself from her marriage as part of this life changing experience and took control of her life with support from the women's education centre. The centre provided a safe space where she could begin to reflect on her life and share her personal problems collectively with others. She explains the main barrier to her participation 'was my educational background'. At the age of 11 , she was segregated from her primary school classmates by the 11 plus that defined children's ability at a very young age. Theresa explains, 'that was something that scarred me for life'.

With the support of committed tutors, Theresa began to engage in community-based informal learning and personal and social development courses. This pathway enabled Theresa to manage problems arising from her own set of personal circumstances, including poor education, before engaging in second chance education to achieve long awaited qualifications. Such problems arise from the legacy of socio-economic structural changes that have affected this community, causing poverty, ontological insecurity, poor mental health, and a poor working class education.

She recalls her learning journey:

When I first started I did nothing academic I did all interest courses. Aromatherapy, the New Me Course and confidence building courses. Therapeutic courses for a couple of years and when I got my confidence back I did Maths and English at ' $O$ ' level at Market College to bring me up to some sort of standard. I continued to study at the college and achieved the Counselling level 2 qualification and then I went up there to do my Certificate in Education so I could be a tutor at the centre.

Theresa has shown loyalty to her learning community by offering the following services to women with poor mental health. She explains,

It was such a community (the centre) that had given me so much and so I wanted to support it. I did the drop in service through offering one to one mentoring support, listening service as it had enhanced my life. Now I have a job which is satisfying to me as I support other women who have difficulties. I am a tutor and I teach Counselling and Personal Development and I have undertaken volunteer work in the Mental Health Sector.

Theresa's story has been one of loss, but also of redemption. It has resulted in a new found freedom that has allowed her to become a loyal and confident learning champion and a role model to women who have also suffered from mental health difficulties. She claims that she has a new self-belief: 'I now know who I am [and] I don't feel inferior at all to anybody'.

\section{Discussion}

For clarification, the Employability programmes are mandatory requirements of welfare reform, whereas community education programmes are voluntary. Those attending the Employability 
programmes are unemployed and claiming welfare payments through Employment Support Allowance for themselves and, in some cases, for their families. It is a conditional requirement of the welfare state that claimants attend these programmes in return for a meagre welfare payment if they have not succeeded in finding a job within a limited time period, as set by the state.

Those attending the Employability programme are prohibited from attending daytime community adult education courses as they must make themselves available for work by being present in the programme on a daily basis. Those participating in community adult education attend voluntarily and choose courses that will meet their educational needs. None of the learners in this study were employed when engaging with community education, but once educated, they became paid or unpaid workers in community bases. There is no cross over between learners going between government programmes and community adult education programmes.

All of the learners interviewed that were participants in the Employability Skills Programme had, like Brian, been unemployed for between one and eight years, but were constantly recycled and coerced into government training schemes after short periods of employment. This did not ultimately construct a positive sense of identity, but reinforced feelings of failure in these learners. The key benefit of participation in these programmes was not related to the stated primary purpose of finding secure and worthwhile employment, but rather the opportunity for social contact in particular, as Brian illustrated, with programme tutors. Programme tutors can be viewed positively, as in Brian's case, by participants, which may reflect recent research by Allatt and Tett (2018), illustrating that employability tutors can, in some cases, use their agency to resist the neoliberal construction of learners as deficit, creatively keeping learners and their goals at the centre of the programme and affording participants some measure of recognition and respect.

As Brian's narrative illustrates, since leaving full time education, these learners have weaved in and out of short-term, lifelong learning government programmes and short-term, poor quality work. This has persisted throughout their working life. According to Shildrick (2015, p. 7), "churning" is where workless welfare claimants (those actively seeking work) "move in and out of low-paid, short-term jobs, and on and off benefits", but in these cases, lifelong learning is also part of the churning process. Bauman (2001, p. 25) describes today's workplace as a "camping site" where one spends an itinerant few days before being moved on.

The analysis of these learners' lives shows a much deeper understanding of churning. These learners supply not only a precarious labour market that offers poor quality work that is low waged, non-unionised, and insecure, but as workless welfare claimants, they have become a pool of cheap labour, to be called upon to supply the market when it dictates, and to be disposed of when no longer required. In doing so, they are socially controlled by the state and capitalists:

Workless individuals who were formerly low paid when they return to employment it is to a similarly low level of earnings and insecure employment ... this low-pay, no-pay cycle means that they find it difficult to escape low living standards and advance in the world of work. (Thompson 2015, p. 4)

Churning through poor quality work creates a precarious existence, a life of poverty, poor mental health, and no way out for these learners. Three of the learners suffered from poor mental health. They expressed concern that no matter how hard they try, they are going nowhere and blame themselves for their unemployed status. The learners work hard to maintain a positive attitude throughout the churning process; otherwise, coercive and disciplinary action will be taken against them. Not only are these vulnerable learners surveilled electronically while in attendance at the Employability Skills Programme and Job Centre interviews, but they are also subject to coercive methods through psychological interventions that are considered to bring about attitudinal behavioural changes in learners, who must have 'work-appropriate attitudes' to achieve employability.

The strict and conditional requirements of welfare are a cause of their anxiety. They remain motivated and committed in their struggle to find (in) secure work, no matter how frustrated they 
feel, but the low level qualifications achieved through these training programmes do not help to move these learners into work and out of poverty. Shildrick and Rucell $(2015$, p. 1) point out that "people's social class positions still influence the opportunities open to them ... starting out in life in poverty means a greater risk of poverty in later life". Also, a deficient local labour market that offers few opportunities and is controlled by private employment agencies simply perpetuates the cycle of insecure, poor quality work that leads to poverty.

None of the learners in this sample own a car, nor do they have sufficient money to give them the freedom to travel out of deprived areas to find work, or to buy essential food at cheaper prices. They do not have the money to join in and engage with the civic, voluntary, social, and cultural activities of their communities, and as a consequence of this, their voices are not heard.

These learners have become not just excluded from the economy, but due to the relative poverty within which they live, they have also been excluded from their community. According to Wolff et al. $(2015$, p. 3), relative poverty is defined as not allowing one to "take part in the normal or encouraged activities of one's society". Therefore, these learners have been socially excluded from equal participation in community activities. These factors have resulted in them exiting their community in a social sense. They remain silently loyal and passive in their communities, but give nothing back to the community.

According to Verba et al. (cited in Lister 2004, p. 149), "poverty and deprivation tend to be associated with lower levels of political and civic activity and collective action than among the wider population". This can encourage an 'image' of the poor as not engaging in activism when in fact they are "denied political agency, the capacity for activism and even the rights of citizenship" (Goode and Maskovsky 2001, p. 14). Since 2008, austerity measures have increased poverty and deprivation through Welfare Reform that has reduced welfare benefits and cut local authority budgets. The latter has led to the breakdown of the public and voluntary organisational infrastructures that managed volunteer projects and engaged communities. The loss of this funding and infrastructure has denied these communities of opportunities to choose volunteer roles to engage in local activism. This may have deepened passivity and silence within these learners. Community solidarity in economic, social, and cultural life has been replaced by a culture of individualism, which puts the onus on the individual to look after themself and not their neighbour.

Theresa's story, like the others in this study, disclosed that kinship was an effective survival strategy for families in the face of economic difficulties for mutual aid, emotional support, and jobs. This form of solidarity practised within families and across different households by women was overturned by the economic shock of deindustrialisation. These stories explain how kinship relationships that were shaped through surviving economic difficulties over many generations became emotionally charged at the time of the Miners' Strike in 1985, contributing to a break-up of kinship practices. A key effect of the loss of kinship is social isolation and a culture of individualism.

However, Theresa's story is a redemptive story as she explains how she has overcome difficulties in her own life and how community education has enabled her to be of value to others in her community. Community adult education is different from the government's Employability Skills Programme in that it does not use coercion. Instead, it seeks the approval, consent, and agreement of the learner, and negotiates with them a curriculum that meets their needs. In doing so, it establishes trust with the learners, who engage in dialogue on issues that matter in their lives, as well as offering them opportunities to engage in bringing about social change. This approach nurtures voice and loyalty to, rather than exit from, their deteriorating communities. Learners may come to see they have some degree of control over situations they thought were beyond their control. In addition, community adult education projects not only build trust, but also provide a sense of belonging to a new community. Learners are given time and attention, they are given respect, they are provided with opportunities of their choice, their isolation is reduced, and they are seen to have "use value" (Skeggs 2005, p. 965). This counteracts exit, and these community learners stay to fight: they do not take flight and become complacent, as is the case with the Employability Skills Programme learners, 
who were seen to exit in a social sense. In remaining loyal and using their once unheard voices, they seek to bring about change from within their communities. In doing so, they contribute to rebuilding their deteriorating communities.

Those participating in community adult education illustrated resistance to being devalued by political elites by creating their own system of value through participation in, and loyalty to, community adult education. In doing so, this improved participants' mental health and reduced their levels of anxiety. As one participant, Barry, stated, this is because he has 'a purpose in life' that had been taken away through deindustrialisation. Once educated, they put to good use their working class values of care and compassion in a collective way to support others. Although they live in left behind communities, they have not allowed themselves to be left behind, and are not allowing others to be left behind by engaging them in community learning. This has enabled these research participants to increase in confidence and to feel valued and useful once more through the power of community relationships and not through value premised on economic exchange.

\section{Conclusions}

Although a relatively small sample, the qualitative depth of the stories in this study reveals some important findings. The learners in Employability Skills Programmes are not individually or collectively connected to the wider community through social, civic, and cultural activities. This is partly due to relative deprivation, but also because they have withdrawn or 'exited' in a social sense from communities that have become socially fragmented. In contrast, those learners attending community adult education had a different experience, although they too came from the same socio-economic background. Ontological insecurity also affected this cohort of learners attending community adult education as it had a very similar effect on people's sense of self and their capacity to act. It was purposeful intervention - by different forms of adult education-that enabled these learners to shape a different subjectivity. In the case of community education, subjectivity was strengthened and in the case of government programmes, subjectivity was weakened.

The Employability Skills Programme and the liberating models of community adult education tend to create very different subjectivities, as a consequence of a very different pedagogy. The Employability Skills Programme is strict and conditional and has psychological interventions where learners are subordinated to its prescriptive requirements. This does not provide exit to work, but it does produce learners who are anxious, fearful, insecure subjects who have exited in a social sense from their community. In adult education, learners are treated as citizens who have something to contribute to others and their community. A Freirean critical pedagogy enables learners to become critical thinkers and this enables knowledge to be actively constructed between learners and tutors. In doing so, the private problems of individuals can become collective issues for social action and political engagement. These learners, once educated, stayed to fight and, in doing so, their once unheard voices now seek to call for social change within their communities. In this way, the different traditions of community adult education can be seen as a resource not only for resistance against deteriorating communities and social inequalities, but also in strengthening the subjectivity of its learners.

Author Contributions: Conceptualization, Jo Forster; Investigation, Jo Forster; Methodology, Jo Forster; Supervision, Jim Crowther; Validation, Jo Forster; Writing-original draft, Jo Forster and Margaret Petrie; Writing-review \& editing, Jim Crowther.

Funding: This research received no external funding.

Conflicts of Interest: The authors declare no conflict of interest

\section{References}

Allatt, Gwyneth, and Lyn Tett. 2018. Adult Literacy Practitioners and employability skills: Resisting neoliberalism. Journal of Education Policy, 1-35. [CrossRef] 
Barr, Jean. 1999. Liberating Knowledge: Research, Feminism and Adult Education; Leicester: National Institute of Adult Continuing Education.

Bauman, Zygmunt. 2001. The Individualised Society. Cambridge: Polity Press, Available online: https://www. amazon.co.uk/Individualized-Society-ZygmuntBauman/dp/074562507X (accessed on 15 September 2015).

Beynon, Hugh, Ray Hudson, and David Sadler. 1986. Horden Colliery, County Durham. In The Enemy within Pit Villages and the Miners' Strike 1984-1985. Edited by R. Samuel, B. Bloomfield and G. Boanas. London: Routledge, pp. 43-51.

Beynon, Hugh, Ray Hudson, and David Sadler. 1991. A Tale of 2 Industries: The Contraction of Coal and Steel in North East of England. Milton Keynes: Open University Press.

Biesta, Gert. 2006. What's the Point of Lifelong Learning if Lifelong Learning Has No Point? On Democratic Deficit of Policies for Lifelong Learning. European Educational Research Journal 5: 169-80.

Bowl, Marion. 2014. Adult Education in Changing Times: Policies, Philosophies and Professionalism; Leicester: NIACE.

Brine, Jacky. 2006. Lifelong Learning and the Knowledge Economy: Those that know and those that do not? The discourse of the European Union. British Educational Research Journal 32: 649-65. [CrossRef]

Brookfield, Stephen. 1983. Adult Learners, Adult Education and the Community. Milton Keynes: Open University Press.

Chamberlayne, Prue, M. Rustin, Joanna Bornat, and Tom Wengraf, eds. 2000. Turn to Biographical Methods in Social Science. Abingdon: Taylor and Francis.

Coffield, Frank. 1999. Breaking the Consensus: Lifelong Learning as Social Control. British Educational Research Journal 25: 479-99. [CrossRef]

Coffield, Frank. 2006. Running Ever Faster down the Wrong Road: An Alternative Future for Education and Skills. Inaugural Lecture at the Institute of Education, University of London, December 5. Available online: http:/ / www.leeds.ac.uk/educol/documents/164948.htm (accessed on 29 August 2017).

Cohen, Louis, Lawrence Manion, and Keith Morrison. 2011. Research Methods in Education, 7th ed. London and New York: Routledge.

Commission of the European Communities (CEC). 1993. White Paper: Growth, Competitiveness, Employment: The Challenges and Ways Forward into the 21st Century. Luxembourg: Office for Official Publications of the European Communities.

County Durham Public Mental Health Strategy 2013-2017. Available online: https://democracy.durham. gov.uk/documents/s35630/Item\%208b\%20-\%20Public\%20Mental\%20Health\%20Strategy.pdf (accessed on 13 August 2018).

County Durham Alcohol Harm Reduction Strategy. 2015. County Durham Alcohol Harm Reduction Strategy 2012-2015. Available online: http://www.durham.gov.uk/media/4073/Safe-Durham-Alcohol-HarmReductionStrategy-2012---2015/pdf/AlcoholHarmReductionStrategy.pdf (accessed on 30 May 2016).

Danson, Mike, Ailsa McKay, and Willie Sullivan. 2015. Supporting the UKs Worklessness. An International Comparative Perspective. Social Policy and Administration 49: 277-98. [CrossRef]

Denzin, Norman K. 1989. Interpretative Biography. Newbury Park: Sage.

Ecclestone, Kathryn, and Dennis Hayes. 2009. The Dangerous Rise of Therapeutic Education. London: Routledge.

Foster, David. 2017. Adult Further Education Funding in England since 2010. A House of Commons Library, Briefing Paper No. 7708. April 21. Available online: https://researchbriefings.parliament.uk/ ResearchBriefing/Summary/CBP-7708 (accessed on 19 October 2018).

Boniface, Priscilla, Mike Robinson, and Peter Fowler. 2001. Pride and Prejudice: Two Cultures and the North East's Transition. In A Region in Transition: North East England at the Millennium. Edited by John Tomaney. Farnham: Ashgate Publishing, pp. 120-35.

Friedli, Lynne, and Robert Stearn. 2015. A positive affect as coercive strategy: Conditionality, Activation and the Role of Psychology in the UK Government Work Programme. Medical Humanities 41: 40-47. [CrossRef] [PubMed]

Freire, Paulo. 1972. Pedagogy of the Oppressed. Harmondsworth: Penguin Books.

Goode, Judith G., and Jeff Maskovsky. 2001. The New Poverty Studies: The Ethnography of Power, Poli and Impoverished People in the United States of America. New York: New York University Press.

Goodson, Ivor F. 1992. Studying Teachers' Lives: An emergent field of inquiry. In Studying Teachers' Lives. Edited by Ivor F. Goodson. London: Routledge, pp. 1-17. 
Harkness, Susan, Stephen Machin, and Jane Waldfogel. 1994. Women's Pay and Family Income Inequality. Joseph Rowntree Foundation, Findings Social Policy Research No. 60. Available online: https://www.jrf. org.uk/file/37521/download?token=6luOr-Wu\&filetype=findings (accessed on 19 October 2018).

Hatch, J. Amos, and Richard Wisniewski. 2003. Life and Narrative; questions, issues and exemplary works. In Life History and Narrative. Edited by Hatch J. Amos and Richard Wisniewski. London: Falmer Press, pp. 113-37.

Jackson, Keith. 1995. Popular Education and the State: A New Look at the Community Debate. In Adult Learning, Critical Intelligence and Social Change. Edited by Marjorie Mayo and Jane Thompson. Leicester and Cardiff: NIACE, pp. 182-202.

Jarvis, Peter. 2010. Adult Education and Lifelong Learning, 4th ed. London: Routledge.

Johnson, Rennie. 1988. Really useful knowledge 1790-1850: Memories for Education in the 1980s. In Radical Approaches to Adult Education. Edited by Tom Lovett. London: Routledge, pp. 3-34.

Johnston, Rennie. 1992. Education for Unwaged Adults: Relevance, Social Control and Empowerment. In Education and Community: The Politics of Practice. Edited by G. Allen and I. Martin. London: Cassell, pp. 66-76.

Lister, R. 2004. Poverty. Cambridge: Polity Press.

Lovett, Tom. 1975. Adult Education, Community Development and the Working Class. London: Ward Lock Education.

Mackenzie, Suzanne, and Damaris Rose. 1982. Industrial change, the domestic economy and home life. In Redundant Spaces in Cities and Regions: Studies in Industrial Decline and Social Change. Edited by James Anderson, Simon Duncan and Ray Hudson. London: Academic Press, pp. 166-82.

McQuaid, Ronald W., and Colin Lindsay. 2005. The Concept of Employability. Urban Studies 42: 177-219. [CrossRef]

Martin, Ian. 2008. Reclaiming Social Purpose: Framing the Discussion. In Reclaiming Social Purpose in Community Education. The Edinburgh Papers: pp. 9-12. Available online: https://criticallychatting.files.wordpress.com/ 2008/11/theedinburghpapers-pdf.pdf (accessed on 1 December 2017).

Merrill, Barbara, and Linden West. 2009. Using Biographical Methods in Social Research. London: Sage.

County Durham Joint Strategic Needs Assessment. Key Messages. 2015. Available online: https://www.durham. gov.uk/media/9140/JSNA-2015keymessages/pdf/CountyDurhamJSNAKeyMessages2015.pdf (accessed on 30 May 2016).

O'Hara, Mary. 2014. Austerity Bites a Journey to the Sharp End of the Cuts in UK. Bristol: Polity Press.

Pimlott, Ben. 1981. The North East: Back to 1930s. In Unemployment. Edited by B. Crick. London: Methuen, p. 51.

Reay, Diane. 2006. The Zombie Stalking English Schools: Social Class and Educational Inequality. British Journal of Educational Studies 54: 288-307. [CrossRef]

County Durham Domestic Abuse and Sexual Violence Strategy (2015-2018). Available online: https: / /www.durham.gov.uk/media /10940/Domestic-Abuse-and-Sexual-Violence-Strategy-2015-

2018/pdf/CountyDurhamDomesticAbuseAndSexualViolenceStrategy2015-2018.pdf (accessed on 19 October 2018).

Savage, Mike. 2015. Social Class in the 21st Century. UK: Penguin Books.

Sayer, Andrew. 2002. "What are you worth?": Why class is an embarrassing subject. Sociological Research Online 7: 1-20. [CrossRef]

Sayer, Andrew. 2005. The Moral Significance of Class. Cambridge: Cambridge University Press.

Sayer, Andrew. 2010. Class and Morality. In Handbook of the Sociology of Morality. Edited by Steven Hitlin and Stephen Vaisey. New York: Springer, pp. 163-78.

Sayer, Andrew. 2015. Why We Can't Afford the Rich. Bristol: Chicago Policy Press.

Seabrook, Jeremy. 1982. Unemployment. London: Quartet Books.

Shildrick, Tracy. 2015. Low pay, no pay: The hidden story of work and worklessness. Poverty 142: 6-9.

Shildrick, Tracy, and Jessica Rucell. 2015. Sociological Perspectives on Poverty: A Review of Sociological Theories on the Causes of Poverty. Report by Joseph Rowntree Foundation, Inspiring Social Change. Available online: https:/ / www.jrf.org.uk/report/sociological-perspectives-poverty (accessed on 14 July 2015).

Skeggs, Beverley. 1997. Formations of Class and Gender: Becoming Respectable. London: Sage.

Skeggs, Bev. 2005. The Making of Class and Gender through Visualising Moral Subject Formation. Sociology 39: 965-82. [CrossRef] 
Skeggs, Beverley. 2013. Class Self Culture. London: Routledge, Taylor and Francis Group, Available online: https:/ / www.taylorfrancis.com/books/9781136499210 (accessed on 19 July 2016).

Skills Funding Agency. 2013. Presentation on Community Learning 2013-2014. Available online: https:/ / www.gov.uk/government/uploads/system/uploads/attachment_data/file/283876/ FINALCommunity_Learning_2013-14_Web_Version.pdf (accessed on 4 November 2014).

Taylor, Richard. 1986. Problems of Inequality: The Nature of Adult Education in Britain. In Adult Education for the Working Class: Education for the Missing Millions. Edited by Kevin Ward and Richard Taylor. R. Croom Helm: Beckenham, pp. 1-26.

Thompson, Jane. 2007. More Words in Edgeways; Leicester and Cardiff: NIACE.

Thompson, Spencer. 2015. The Low-Pay, No-Pay Cycle. Report by Joseph Rowntree Trust. Available online: https: / /www.jrf.org.uk/report/low-pay-no-pay-cycle (accessed on 14 October 2015).

Trade Union Council. 2014. Austerity Uncovered Final Report. Centre for Local Economic Strategies. Available online: https:/ / cles.org.uk/wp-content/uploads/2016/10/TUC-Final-Report.pdf (accessed on 17 January 2016).

University of Edinburgh. 2012. Moray House School of Education, Research Ethics policy and procedures. August. Available online: https://www.ed.ac.uk/education/rke/research-support/ethics/approval-processes (accessed on 17 August 2012).

VONNE. 2014. [Report] Surviving or Thriving? State of the Sector in the North East: North East Charities Struggling to Meet Demand as Welfare Reform Bites. Newcastle: Voluntary Organisations Network North East, pp. 1-3. Available online: https://www.vonne.org.uk/campaigns/surviving-or-thriving (accessed on 20 October 2017).

Walkerdine, Valerie. 2009. Steel, Identity, Community: Regenerating Identities in a South Wales Town. In Identity in the 21st Century: New Trends in Changing Times. Edited by Margaret Weatherell. Basingstoke: Palgrave Macmillan.

Walkerdine, Valerie. 2010. Communal Beingness and Affect: An exploration of trauma in an ex-industrial community. Body and Society 16: 91-120. [CrossRef]

Walkerdine, Valerie, and Luis Jimenez. 2012. Gender, Work and Community after Deindustrialisation: A Psychosocial Approach to Affect. Basingstoke: Palgrave.

Welfare Reform Act. 2009, c.24. Available online: https://www.legislation.gov.uk/ukpga/2009/24/contents (accessed on 22 November 2017).

Welfare Reform Act. 2012a, c.5. Available online: http://www.legislation.gov.uk/ukpga/2012/5/contents/ enacted (accessed on 21 November 2017).

Welfare Reform Act. 2012b, Section 16, Work Related Requirements and Health Assessment. Available online: https: / www.legislation.gov.uk/ukpga/2012/5/section/16 (accessed on 21 November 2017).

Welfare Reform Act. 2013, c.17. Jobseekers (Back to Work Scheme). Available online: http:/ /www.legislation.gov. uk/ukpga/2013/17/contents/enacted (accessed on 21 November 2017).

Welfare Reform and Work Act. 2016, c.7. Available online: https://www.legislation.gov.uk/ukpga/2016/7/ contents (accessed on 21 November 2017).

Willis, Peter. 1991. Community education in Australia: Reflections on an expanding field of practice. Australian Journal of Adult and Community Education 31: 71-87.

Wolff, Jonathan, Edward Lamb, and Eliana Zur-Szpiro. 2015. A Philosophical Review of Poverty. Joseph Rowntree Foundation, Inspiring Social Change Report. Available online: https://www.jrf.org. uk/report/philosophical-review-poverty (accessed on 14 July 2015).

Wray, David, and Carol Stephenson. 2012. 'Standing the Gaff': Immiseration and its consequences in the de-industrialised mining communities of Cape Bretton Island. Capital and Class 36: 323-38. [CrossRef]

Mills, C. Wright. 1970. The Sociological Imagination. Harmondsworth: Penguin. First published 1959.

(C) 2018 by the authors. Licensee MDPI, Basel, Switzerland. This article is an open access article distributed under the terms and conditions of the Creative Commons Attribution (CC BY) license (http:/ / creativecommons.org/licenses/by/4.0/). 